\title{
What's the difference? A gender perspective on understanding educational inequalities in all-cause and cause-specific mortality
}

Karen van Hedel ${ }^{1,2}$, Frank J. van Lenthe ${ }^{1 *}$, Joost Oude Groeniger ${ }^{1}$ and Johan P. Mackenbach ${ }^{1}$

\begin{abstract}
Background: Material and behavioural factors play an important role in explaining educational inequalities in mortality, but gender differences in these contributions have received little attention thus far. We examined the contribution of a range of possible mediators to relative educational inequalities in mortality for men and women separately.

Methods: Baseline data (1991) of men and women aged 25 to 74 years participating in the prospective Dutch GLOBE study were linked to almost 23 years of mortality follow-up from Dutch registry data (6099 men and 6935 women). Cox proportional hazard models were used to calculate hazard ratios with $95 \%$ confidence intervals, and to investigate the contribution of material (financial difficulties, housing tenure, health insurance), employmentrelated (type of employment, occupational class of the breadwinner), behavioural (alcohol consumption, smoking, leisure and sports physical activity, body mass index) and family-related factors (marital status, living arrangement, number of children) to educational inequalities in all-cause and cause-specific mortality, i.e. mortality from cancer, cardiovascular disease, other diseases and external causes.
\end{abstract}

Results: Educational gradients in mortality were found for both men and women. All factors together explained $62 \%$ of educational inequalities in mortality for lowest educated men, and $71 \%$ for lowest educated women. Yet, type of employment contributed substantially more to the explanation of educational inequalities in all-cause mortality for men (29\%) than for women (-7\%), whereas the breadwinner's occupational class contributed more for women (41\%) than for men (7\%). Material factors and employment-related factors contributed more to inequalities in mortality from cardiovascular disease for men than for women, but they explained more of the inequalities in cancer mortality for women than for men.

Conclusions: Gender differences in the contribution of employment-related factors to the explanation of educational inequalities in all-cause mortality were found, but not of material, behavioural or family-related factors. A full understanding of educational inequalities in mortality benefits from a gender perspective, particularly when considering employment-related factors.

Keywords: Education, Gender differences, Socioeconomic inequalities, Mortality

\footnotetext{
* Correspondence: f.vanlenthe@erasmusmc.nl

'Department of Public Health, Erasmus MC, P.O. Box 2040, 3000, CA,

Rotterdam, The Netherlands

Full list of author information is available at the end of the article
}

(c) The Author(s). 2018 Open Access This article is distributed under the terms of the Creative Commons Attribution 4.0 International License (http://creativecommons.org/licenses/by/4.0/), which permits unrestricted use, distribution, and reproduction in any medium, provided you give appropriate credit to the original author(s) and the source, provide a link to the Creative Commons license, and indicate if changes were made. The Creative Commons Public Domain Dedication waiver (http://creativecommons.org/publicdomain/zero/1.0/) applies to the data made available in this article, unless otherwise stated. 


\section{Background}

Higher levels of education are related to lower rates of all-cause and cause-specific mortality in most European countries including the Netherlands [1-6]. Prior studies highlighted the importance of material factors (e.g., income, type of health insurance, and financial difficulties) and behavioural factors (e.g., smoking, excessive alcohol consumption, and diet) in explaining educational inequalities in mortality [7-12]. Educational gradients in mortality have been found for both men and women [4, 5]. Absolute mortality differences by education are generally larger for men than for women, but gender differences in relative mortality differences by education are less clear [13, 14]. These findings suggest that explanations for the educational gradient may also differ for men and women, an issue that hardly received attention thus far.

Indeed, two mechanisms may explain why material and behavioural factors contribute differently to the explanation of educational inequalities in mortality between men and women. Firstly, the impact of education on material, employment-related and behavioural factors may differ. For example, socioeconomic inequalities in overweight are smaller for Dutch men than for Dutch women [15], and educational inequalities in smoking prevalence were larger for men than for women in the European Union [16]. Secondly, the effect of material, employment-related and behavioural factors on mortality may differ. For example, unemployment is more strongly related to mortality for men than for women, which may be the result of employment status being more central to men's identities than to women's [17].

In addition, family-related factors may play a role in generating gender differences in educational inequalities in mortality. The educational gradient in family factors may be different for men and women. Indeed, higher educated men and women are more likely to ever get married than their lower educated counterparts, but this marriage gap seems to be larger for men than for women [18, 19]. Additionally, higher educated Dutch women are more likely to remain childless than low educated women, whereas the proportion of Dutch men that remains childless is similar across different educational levels [19]. Additionally, mortality differentials by marital status, living arrangement and parenthood status have been found; mortality is lower for married individuals, individuals living with a partner, or parents, than for their unmarried, living alone, and childless counterparts, respectively [20-22]. These family factors may also differentially impact mortality of men and women. For example, marriage is more protective of health and mortality for men than for women [23]. There seem to be no clear gender differences in the association between parenthood and mortality [24, 25]. To our knowledge the contribution of these factors to educational inequalities in mortality has not yet been studied.

A proper understanding of the underlying causes of inequalities in mortality is needed for adequate interventions and policies aimed at bridging the health gap between the higher and lower educated. Perhaps surprisingly, and despite good reasons to assume that the explanation of socioeconomic inequalities in health may differ by gender, only few studies investigated this with a specific gender perspective [26-29]. The aim of this article was to examine whether explanations for relative educational inequalities in mortality differed between men and women. We examined multiple material, employment-related, behavioural and family-related factors, using data from a Dutch cohort study linked on an individual level to registry data with almost 23 years of mortality follow-up.

\section{Methods}

Data came from the prospective GLOBE study (the Dutch acronym for Health and Living Conditions of the Population of Eindhoven and surroundings) [30] initiated to quantitatively assess mechanisms and factors explaining socioeconomic inequalities in health in the Netherlands [31]. Baseline information was collected through a postal survey in 1991. This survey was distributed among 27,070 non-institutionalized respondents aged 15 to 74 years living in Eindhoven, a city in the South of the Netherlands, and its surrounding municipalities [32]. The response for this postal survey was $70.1 \%$, leaving 18,973 respondents in the baseline sample. This sample was then on an individual level linked (94\%) to almost 23 years of mortality follow-up from Statistics Netherlands.

Men and women aged 25 to 74 years were included in our study $(n=15,534)$. We excluded those who reported at least one of six severe chronic diseases (chronic obstructive pulmonary disease, heart disease, stroke, renal disease, diabetes, or cancer) at baseline $(n=2500)$. Having a chronic illness may influence an individual's survival, but it may also affect their explanatory factors such as health behaviours. For example, individuals may improve their health behaviours after a health scare due to chronic illness, e.g. cease smoking, eat healthier or become more physically active. However, our explanatory variables may also have influenced the likelihood of becoming chronically ill, as unhealthy behaviours increase the chance of becoming chronically ill [33]. As no information was available prior to our baseline data in 1991, we cannot disentangle how these two mechanisms might be working together due to lack of a time dimension. Overall, our analyses included 6099 men and 6935 women. 


\section{Levels of education}

Educational level was used to represent the socioeconomic position of the individual, as it is commonly used as an indicator for socioeconomic status in the Netherlands. We distinguished 4 levels of educational attainment with the following equivalent levels of the International Standard Classification of Education (ISCED) [34]: primary education only ("lowest", ISCED 0 and 1), lower vocational school and lower secondary school ("low", ISCED 2), intermediate vocational school and intermediate or higher secondary school ("mid", ISCED 3 and 4), and higher vocational school and university ("high", ISCED 5 and 6).

\section{Explanatory variables: material, employment-related, behavioural and family-related factors}

All explanatory factors were derived from the postal survey collected in 1991. Financial problems, housing tenure and health insurance were included as material factors. Financial problems were measured by asking the respondents if they had any difficulties paying bills, food, rent, electricity, etcetera during the previous year (no difficulties, some difficulties, and big difficulties). With regards to housing tenure, we distinguished between individuals owning and those renting their home. The two possible types of health insurance were public and private insurance. As employment-related factors, we included the respondent's employment status (employed; unemployed; retired; others, e.g. students or homemakers) and the occupation of the main breadwinner (professional; white-collar; blue-collar occupations; not in the workforce) [35].

The behavioural factors included in this study were alcohol consumption, smoking, physical activity in leisure time, physical activity in sports, and body mass index (BMI). Alcohol consumption (weekly number of drinks) was calculated from information on the number of days per week the respondent drank alcoholic drinks and the number of alcoholic drinks (units) consumed on such a day; no consumption, light consumption ( 1 to 14 drinks for men, 1 to 7 drinks for women), moderate consumption (15 to 21 drinks for men, 8 to 14 drinks for women), and heavy consumption (22 or more drinks for men, 15 or more drinks for women; same cut-off as used by Statistics Netherlands to define excess alcohol consumption). Regarding smoking status, we distinguished current smokers from former smokers and never smokers. Physical activity in leisure time was measured by two questions "How many hours of your leisure time do you spend in total per week on working in the garden, biking, walking, walking the dog?" and "How many hours of your leisure time do you spend in total per week on chores, fixing the house, repairs?". Sports physical activity was measured by the question "Do you exercise?". Both physical activity questions had the following
4 answer categories; (i) no, (almost) never ("inactive"), (ii) yes, less than $1 \mathrm{~h}$ a week ("little active"), (iii) yes, approximately 1 to $2 \mathrm{~h}$ a week ("moderately active"), and (iv) yes, $2 \mathrm{~h}$ a week or more ("active"). BMI $\left(\mathrm{kg} / \mathrm{m}^{2}\right)$ was calculated from self-reported weight and height (underweight, $\mathrm{BMI}<20$; normal weight, $20 \leq \mathrm{BMI}<25$; overweight, $25 \leq \mathrm{BMI} \leq 30$; or obese, $\mathrm{BMI}>30$ ). BMI was included here as it is mainly determined by behaviour.

As family-related factors we included marital status, living arrangement and number of children. Marital status was categorized into currently married, previously married (i.e., divorced and widowed) and never married. We also included living arrangement (living together with a partner or living alone). Lastly, we distinguished between no, one, two, and three or more children.

\section{Outcome measures}

Mortality data were obtained from Statistics Netherlands. The GLOBE baseline survey (April 1, 1991) was linked to death registry data until December 31, 2013, allowing for almost 23 years of mortality follow-up. We examined educational inequalities in all-cause mortality, as well as in 4 categories of causes of death: mortality from cancer, cardiovascular disease (CVD), other diseases, and external causes. The International Classification of Disease, 10th revision codes [36] for the causes of death included in each of these categories are provided in the footnote of Table 4.

\section{Analysis}

Missing values for the explanatory factors, but not educational attainment or mortality, were handled by applying multiple imputations $(M=5)[37,38]$. We imputed missing values based on all other factors included in the analysis.

Our analytical strategy consisted of four steps, and essentially follows the steps of a mediation analysis [39]. We thus assume causal effects of education on mortality, of education on the mediators and of the mediators on mortality, as would be done within a mediation analysis. However, we understand that our observational study cannot lead to causal effects, and therefore we refer to our results as associations. First, we calculated hazard ratios (HR) and their 95\% confidence intervals (CI) for the association between educational level and mortality for men and women, using Cox proportional hazard models with age as the time scale (also referred to as model 0). Second, age-standardised prevalence rates of the explanatory factors by educational level were calculated for men and women. Third, Cox proportional hazard models were used to assess the association between each explanatory factor and mortality, adjusted for education (added as an independent variable to the models). Fourth, we estimated hazard 
ratios for education after inclusion of the material, employment-related, behavioural and/or family-related factors in Cox proportional hazard models. The contributions of these factors to educational inequalities in mortality were then estimated based on the changes in the hazard ratios for education after inclusion of these explanatory factors (adjusted models). The absolute change in the hazard ratios (HR) for education after the explanatory factors were included, was calculated by $\mathrm{HR}_{\text {model }}$ - $-\mathrm{HR}_{\text {adjusted. The relative }}$ change was calculated as follows: $\left(\mathrm{HR}_{\text {model }} 0-\mathrm{HR}_{\mathrm{ad}}\right.$ justed $) /\left(\mathrm{HR}_{\text {model }} 0^{-1}\right)$. We estimated the contributions of each explanatory factor to educational inequalities in mortality separately and for the broader categories of factors. Confidence intervals of the contributions to educational inequalities in mortality were calculated using a bootstrap with 5000 repetitions; 1000 repetitions per imputed dataset. The same procedure was used to assess the contributions of the explanatory factors to educational inequalities in cause-specific mortality. Cause-specific mortality was analysed within a competing risks framework [40]; as we were interested in mortality from a specific cause, and wanted to account for the fact that individuals may die from other causes than the one we were interested in. Gender differences in the contribution of material, employment, behavioural and family factors to the explanation of educational inequalities in all-cause and cause-specific mortality were assessed by comparing the estimated $95 \%$ confidence intervals of men and women. Gender differences were determined based on non-overlapping confidence intervals of the contribution of factors to educational inequalities in mortality for men and women.

The Cox proportional hazard models and the multiple imputation strategy were performed using Stata SE version 14.1. The bootstrapped confidence intervals were calculated in $\mathrm{R}$ version 3.3.1.

\section{Results}

As compared to those with the highest levels of education, significantly increased hazard ratios were found for those with lower levels of education (Fig. 1). Whereas an inverse educational gradient in mortality was found for men, reasonably similar hazard ratios were found at all three lower levels of education for women. Proportions of men and women in each educational category, with their 95\% confidence intervals, are presented in Additional file 1: Table S1.

\section{Distribution of explanatory factors by educational level}

Inverse educational gradients were found for all material and employment-related factors, but noticeable differences were found in the size of these gradients between men and women (Table 1). The educational gradient was larger for men than women with regards to the proportion privately insured, unemployed and blue-collar occupation of the breadwinner.

Educational gradients were also found for the behavioural factors, with sometimes contrasting directions between men and women. Specifically, the educational gradient for not consuming any alcohol was weaker for men than for women. Whereas heavy alcohol consumption decreased with increasing educational levels for men, it increased with education for women. The observed gradient in current smoking by educational level was smaller for men than for women, but in the same direction. The proportion of men being moderately active in leisure activities increased with higher levels of education, but the proportion of women being moderately active was similar across educational levels. The educational gradient in being active in leisure activities

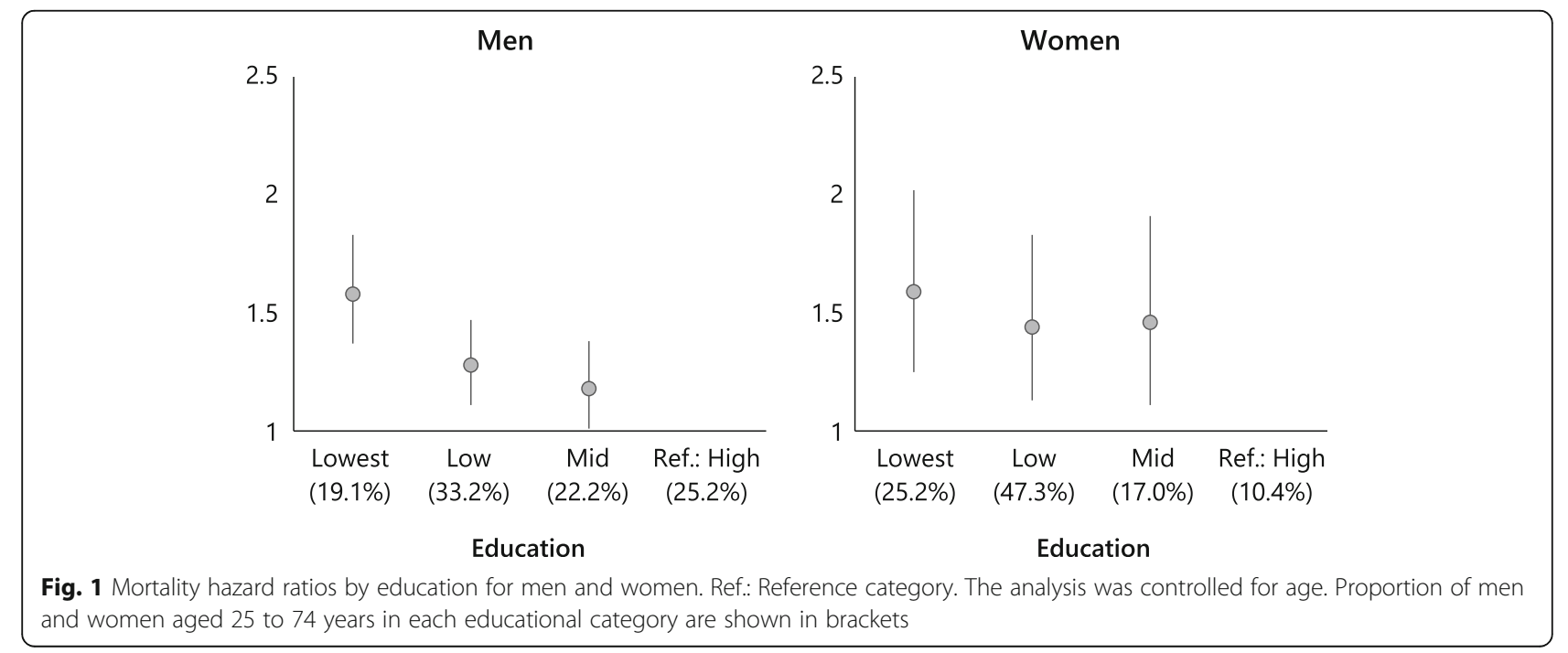


Table 1 Educational gradients in explanatory factors for men and women

\begin{tabular}{|c|c|c|c|c|c|c|c|c|c|}
\hline & \multicolumn{4}{|l|}{ Men } & \multicolumn{4}{|l|}{ Women } & \multirow{2}{*}{$\begin{array}{l}\text { Testing for a gender } \\
\text { difference in } \\
\text { gradient ( } p \text { value) }{ }^{a}\end{array}$} \\
\hline & Lowest & Low & Mid & High & Lowest & Low & Mid & High & \\
\hline \multicolumn{10}{|l|}{ Material factors } \\
\hline \multicolumn{10}{|l|}{ Financial difficulties } \\
\hline No & $65.1 \%$ & $76.2 \%$ & $83.0 \%$ & $92.6 \%$ & $62.9 \%$ & $78.8 \%$ & $83.6 \%$ & $90.0 \%$ & 0.325 \\
\hline Some & $27.4 \%$ & $21.3 \%$ & $14.8 \%$ & $6.5 \%$ & $29.5 \%$ & $17.7 \%$ & $13.8 \%$ & $9.0 \%$ & 0.430 \\
\hline Big & $7.6 \%$ & $2.6 \%$ & $2.1 \%$ & $0.9 \%$ & $7.6 \%$ & $3.5 \%$ & $2.7 \%$ & $1.0 \%$ & 0.303 \\
\hline \multicolumn{10}{|l|}{ Housing tenure } \\
\hline Owned home & $29.5 \%$ & $48.4 \%$ & $62.0 \%$ & $76.5 \%$ & $34.2 \%$ & $53.0 \%$ & $67.3 \%$ & $74.2 \%$ & 0.112 \\
\hline Rented home & $70.5 \%$ & $51.6 \%$ & $38.0 \%$ & $23.5 \%$ & $65.8 \%$ & $47.0 \%$ & $32.7 \%$ & $25.8 \%$ & $"$ \\
\hline \multicolumn{10}{|l|}{ Health insurance } \\
\hline Private & $7.8 \%$ & $27.0 \%$ & $50.6 \%$ & $79.0 \%$ & $15.9 \%$ & $31.2 \%$ & $48.3 \%$ & $66.6 \%$ & $<0.001$ \\
\hline Public & $92.2 \%$ & $73.0 \%$ & $49.4 \%$ & $21.0 \%$ & $84.1 \%$ & $68.8 \%$ & $51.7 \%$ & $33.4 \%$ & $"$ \\
\hline \multicolumn{10}{|l|}{ Employment-related factors } \\
\hline \multicolumn{10}{|l|}{ Employment } \\
\hline Employed & $46.7 \%$ & $60.2 \%$ & $61.0 \%$ & $66.1 \%$ & $18.9 \%$ & $24.4 \%$ & $34.0 \%$ & $41.0 \%$ & 0.932 \\
\hline Unemployed & $27.6 \%$ & $12.7 \%$ & $9.6 \%$ & $4.6 \%$ & $9.7 \%$ & $6.4 \%$ & $4.9 \%$ & $7.1 \%$ & $<0.001$ \\
\hline Retired & $25.1 \%$ & $26.3 \%$ & $27.9 \%$ & $28.4 \%$ & $6.9 \%$ & $7.2 \%$ & $10.0 \%$ & $15.8 \%$ & 0.065 \\
\hline Other & $0.5 \%$ & $0.8 \%$ & $1.6 \%$ & $1.0 \%$ & $64.4 \%$ & $62.0 \%$ & $51.1 \%$ & $36.1 \%$ & $<0.001$ \\
\hline \multicolumn{10}{|c|}{ Occupation of the breadwinner } \\
\hline Professional & $4.2 \%$ & $16.8 \%$ & $44.0 \%$ & $85.3 \%$ & $10.9 \%$ & $25.5 \%$ & $49.6 \%$ & $77.4 \%$ & $<0.001$ \\
\hline White collar & $15.0 \%$ & $23.7 \%$ & $26.9 \%$ & $8.5 \%$ & $14.2 \%$ & $22.3 \%$ & $22.2 \%$ & $11.7 \%$ & 0.001 \\
\hline Blue collar & $78.4 \%$ & $57.9 \%$ & $27.0 \%$ & $4.9 \%$ & $52.4 \%$ & $38.1 \%$ & $18.9 \%$ & $5.6 \%$ & $<0.001$ \\
\hline Not in the workforce & $2.5 \%$ & $1.6 \%$ & $2.2 \%$ & $1.3 \%$ & $22.6 \%$ & $14.2 \%$ & $9.2 \%$ & $5.3 \%$ & 0.001 \\
\hline \multicolumn{10}{|l|}{ Behavioural factors } \\
\hline \multicolumn{10}{|l|}{ Alcohol consumption } \\
\hline No & $20.0 \%$ & $13.0 \%$ & $10.9 \%$ & $6.7 \%$ & $44.9 \%$ & $31.5 \%$ & $21.2 \%$ & $17.2 \%$ & 0.005 \\
\hline Light & $54.9 \%$ & $61.2 \%$ & $62.7 \%$ & $67.6 \%$ & $38.5 \%$ & $47.8 \%$ & $48.6 \%$ & $51.7 \%$ & 0.618 \\
\hline Moderate & $8.5 \%$ & $11.4 \%$ & $12.8 \%$ & $15.1 \%$ & $11.5 \%$ & $13.5 \%$ & $18.6 \%$ & $20.9 \%$ & 0.147 \\
\hline Heavy & $16.7 \%$ & $14.4 \%$ & $13.7 \%$ & $10.5 \%$ & $5.1 \%$ & $7.3 \%$ & $11.5 \%$ & $10.2 \%$ & $<0.001$ \\
\hline \multicolumn{10}{|l|}{ Body mass index (BMI) } \\
\hline Underweight & $4.3 \%$ & $3.4 \%$ & $3.4 \%$ & $4.0 \%$ & $7.2 \%$ & $8.5 \%$ & $10.1 \%$ & $12.1 \%$ & 0.071 \\
\hline Normal weight & $46.2 \%$ & $46.9 \%$ & $55.1 \%$ & $61.8 \%$ & $49.1 \%$ & $56.2 \%$ & $62.1 \%$ & $65.0 \%$ & 0.844 \\
\hline Overweight & $41.8 \%$ & $44.6 \%$ & $37.5 \%$ & $32.4 \%$ & $32.3 \%$ & $28.5 \%$ & $23.5 \%$ & $17.7 \%$ & 0.118 \\
\hline Obese & $7.6 \%$ & $5.1 \%$ & $4.0 \%$ & $1.8 \%$ & $11.4 \%$ & $6.7 \%$ & $4.3 \%$ & $5.2 \%$ & 0.989 \\
\hline \multicolumn{10}{|l|}{ Smoking } \\
\hline Current & $54.8 \%$ & $45.2 \%$ & $38.2 \%$ & $35.4 \%$ & $42.1 \%$ & $32.7 \%$ & $28.9 \%$ & $19.9 \%$ & 0.009 \\
\hline Former & $34.1 \%$ & $40.4 \%$ & $43.5 \%$ & $42.9 \%$ & $21.7 \%$ & $28.2 \%$ & $30.7 \%$ & $32.5 \%$ & 0.181 \\
\hline Never & $11.1 \%$ & $14.5 \%$ & $18.3 \%$ & $21.7 \%$ & $36.2 \%$ & $39.1 \%$ & $40.4 \%$ & $47.7 \%$ & 0.056 \\
\hline \multicolumn{10}{|l|}{ Leisure activity } \\
\hline Inactive & $15.5 \%$ & $11.9 \%$ & $12.2 \%$ & $10.1 \%$ & $18.6 \%$ & $11.7 \%$ & $10.8 \%$ & $7.2 \%$ & 0.003 \\
\hline Little & $12.9 \%$ & $14.0 \%$ & $14.4 \%$ & $16.3 \%$ & $16.8 \%$ & $16.6 \%$ & $15.3 \%$ & $18.4 \%$ & 0.119 \\
\hline Moderate & $22.5 \%$ & $25.1 \%$ & $26.0 \%$ & $28.1 \%$ & $29.7 \%$ & $27.5 \%$ & $29.9 \%$ & $26.7 \%$ & 0.005 \\
\hline Active & $49.1 \%$ & $49.0 \%$ & $47.5 \%$ & $45.5 \%$ & $34.9 \%$ & $44.3 \%$ & $44.0 \%$ & $47.7 \%$ & $<0.001$ \\
\hline
\end{tabular}


Table 1 Educational gradients in explanatory factors for men and women (Continued)

\begin{tabular}{|c|c|c|c|c|c|c|c|c|c|}
\hline & \multicolumn{4}{|l|}{ Men } & \multicolumn{4}{|l|}{ Women } & \multirow{2}{*}{$\begin{array}{l}\text { Testing for a gender } \\
\text { difference in } \\
\text { gradient ( } p \text { value) }{ }^{a}\end{array}$} \\
\hline & Lowest & Low & Mid & High & Lowest & Low & Mid & High & \\
\hline \multicolumn{10}{|l|}{ Sports activity } \\
\hline Inactive & $73.3 \%$ & $60.9 \%$ & $51.6 \%$ & $44.0 \%$ & $72.9 \%$ & $56.9 \%$ & $46.2 \%$ & $43.1 \%$ & 0.320 \\
\hline Little & $4.8 \%$ & $6.6 \%$ & $9.4 \%$ & $8.4 \%$ & $7.2 \%$ & $8.0 \%$ & $8.7 \%$ & $11.3 \%$ & 0.391 \\
\hline Moderate & $9.9 \%$ & $14.3 \%$ & $16.6 \%$ & $23.8 \%$ & $12.4 \%$ & $21.5 \%$ & $26.9 \%$ & $23.3 \%$ & 0.302 \\
\hline Active & $12.0 \%$ & $18.2 \%$ & $22.4 \%$ & $23.8 \%$ & $7.4 \%$ & $13.6 \%$ & $18.2 \%$ & $22.3 \%$ & 0.004 \\
\hline \multicolumn{10}{|l|}{ Family-related factors } \\
\hline \multicolumn{10}{|l|}{ Marital status } \\
\hline Currently married & $73.6 \%$ & $82.1 \%$ & $81.1 \%$ & $77.7 \%$ & $71.5 \%$ & $78.0 \%$ & $72.0 \%$ & $65.9 \%$ & 0.001 \\
\hline Previously married & $10.2 \%$ & $7.5 \%$ & $7.5 \%$ & $8.7 \%$ & $20.4 \%$ & $15.4 \%$ & $14.3 \%$ & $11.2 \%$ & 0.025 \\
\hline Never married & $16.2 \%$ & $10.4 \%$ & $11.4 \%$ & $13.6 \%$ & $8.2 \%$ & $6.6 \%$ & $13.7 \%$ & $22.9 \%$ & $<0.001$ \\
\hline \multicolumn{10}{|l|}{ Living arrangement } \\
\hline Living with partner & $78.0 \%$ & $86.9 \%$ & $86.4 \%$ & $84.2 \%$ & $75.7 \%$ & $81.5 \%$ & $76.7 \%$ & $73.0 \%$ & 0.001 \\
\hline Living alone & $22.0 \%$ & $13.1 \%$ & $13.6 \%$ & $15.8 \%$ & $24.3 \%$ & $18.5 \%$ & $23.3 \%$ & $27.0 \%$ & $"$ \\
\hline \multicolumn{10}{|l|}{ Number of children } \\
\hline 0 & $26.0 \%$ & $18.8 \%$ & $22.3 \%$ & $22.0 \%$ & $12.2 \%$ & $15.2 \%$ & $21.8 \%$ & $32.1 \%$ & $<0.001$ \\
\hline 1 & $16.6 \%$ & $14.0 \%$ & $12.2 \%$ & $7.3 \%$ & $14.4 \%$ & $12.7 \%$ & $10.8 \%$ & $6.9 \%$ & 0.275 \\
\hline 2 & $32.7 \%$ & $38.5 \%$ & $37.5 \%$ & $35.4 \%$ & $42.3 \%$ & $38.5 \%$ & $31.5 \%$ & $29.0 \%$ & $<0.001$ \\
\hline 3 or more & $24.6 \%$ & $28.7 \%$ & $28.1 \%$ & $35.3 \%$ & $31.0 \%$ & $33.6 \%$ & $35.9 \%$ & $32.0 \%$ & 0.015 \\
\hline
\end{tabular}

Notes. Age-standardised towards the age distribution of men and women observed in the data. The imputed values resulting from our multiple imputations strategy were also included in these distributions. ${ }^{a}$ The $p$ value of the difference in the educational gradient for men and women came from interaction models (education $\times$ gender) in which we additionally controlled for age and age $\times$ gender interactions

was similar across educational levels for men, but increased with increasing educational levels for women. The observed educational gradient in being active in sports activity was in the same direction for men and women, although smaller for men than for women.

Educational gradients were least clear for the family-related factors. The proportion of currently married persons was lowest among low educated men and among high educated women. Living alone was less common for men with higher education than those with lower education, but for women it was slightly higher for those with higher levels of education. With increasing levels of education, childlessness slightly decreased for men, but increased for women.

\section{Explanatory factors and their association with mortality}

The associations of all material factors with mortality had comparable magnitudes for both men and women (Table 2). For the employment-related factors, some gender differences were found. Unemployment was associated with higher mortality for men (hazard ratio $(\mathrm{HR})=$ 1.84, 95\% confidence interval (CI): 1.58, 2.14), but not for women $(\mathrm{HR}=1.26,95 \% \mathrm{CI}$ : $0.90,1.64)$. In contrast, blue-collar occupation of the breadwinner was not associated with higher mortality for men $(\mathrm{HR}=1.03,95 \% \mathrm{CI}$ : $0.89,1.19)$, but it was associated with higher mortality for women $(\mathrm{HR}=1.31,95 \% \mathrm{CI}: 1.13,1.52)$. Being a former smoker, being previously married, and living alone was more strongly associated with mortality for men (former smoker vs. never smoker: $\mathrm{HR}=1.33$, 95\% CI: $1.09,1.62$; previously married vs. currently married: $\mathrm{HR}=1.55$, 95\% CI: 1.33, 1.79; and living alone vs. living with a partner: $\mathrm{HR}=1.55,95 \% \mathrm{CI}: 1.35,1.77$ ) than for women $(\mathrm{HR}=0.96,95 \% \mathrm{CI}: 0.84,1.09 ; \mathrm{HR}=1.18,95 \%$ CI: $1.05,1.33$; and $\mathrm{HR}=1.21,95 \% \mathrm{CI}: 1.08,1.35$; respectively).

\section{Contribution to educational inequalities in all-cause mortality}

A statistically significant elevated mortality risk for the lowest educated men and women $(\mathrm{HR}=1.58,95 \% \mathrm{CI}$ : 1.37, 1.83 for men; $H R=1.59,95 \% \mathrm{CI}: 1.25,2.02$ for women; Table 3) was substantially attenuated after accounting for material factors $(67 \%$ for men, $51 \%$ for women), and it was no longer statistically significantly higher among men $(\mathrm{HR}=1.18,95 \% \mathrm{CI}$ : 0.99, 1.40 for men; $\mathrm{HR}=1.29,95 \% \mathrm{CI}: 1.00,1.66$ for women). Type of health insurance seemed to explain more of the excess mortality risk of the lowest educated men (53\%) than of the lowest educated women (32\%). Both employment-related factors together explained a similar share of the educational inequalities for both men (between 21 and 28\%) and women (between 11 and 34\%), but strong differences were found 
Table 2 Bivariate associations between the explanatory factors and mortality for men and women

\begin{tabular}{|c|c|c|c|c|}
\hline \multirow{2}{*}{ 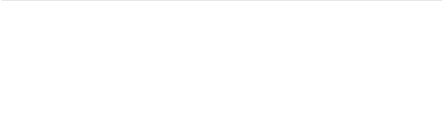 } & Men & \multicolumn{2}{|c|}{ Women } & \multirow{2}{*}{$\begin{array}{l}\text { Testing for a gender } \\
\text { difference in the } \\
\text { bivariate associations } \\
(p \text { value })^{c}\end{array}$} \\
\hline & $(95 \% \mathrm{Cl})^{\mathrm{b}}$ & $\overline{H R^{a}}$ & $(95 \% \mathrm{Cl})^{\mathrm{b}}$ & \\
\hline
\end{tabular}

Material factors

Financial difficulties

No

Some

Big

Housing tenure

Owned home

Rented home

Health insurance

Private

Public

1.34

Employment-related factors

Employment

Employed

Unemployed

Retired

Other

Occupation of the breadwinner

$\begin{array}{ll}\text { Professional } & 1 \\ \text { White collar } & 1.07 \\ \text { Blue collar } & 1.03 \\ \text { Not in the workforce } & 1.27\end{array}$

Behavioural factors

Alcohol consumption

No
Light
Moderate
Heavy

Body mass index (BMI)

Underweight

Normal weight

Overweight

Obesity

1

1.84

1.10

0.92

1.07

.03

1.20

1

1.12

1.71

1.58

1

1.04

1.36

Smoking

Current

2.49

Former

Never

Leisure activity

Inactive

1.43

Little

Moderate

1.28

1.04

Active
Ref.

$(1.02,1.32)$

$(1.06,1.87)$

Ref.

$(1.15,1.43)$

Ref.

$(1.18,1.51)$

Ref.

$(1.58,2.14)$

$(0.95,1.26)$

$(0.47,1.81)$

Ref.

$(0.91,1.25)$

$(0.89,1.19)$

$(0.87,1.85)$

$(1.04,1.38)$

Ref.

$(0.94,1.32)$

$(1.48,1.98)$

$(1.20,2.07)$

Ref.

$(0.94,1.16)$

$(1.07,1.74)$

$(2.05,3.02)$

$(1.09,1.62)$

Ref.

$(1.21,1.69)$

$(1.10,1.50)$

$(0.92,1.17)$

Ref.
Ref.

$\begin{array}{ll}(1.13,1.46) & 0.278\end{array}$

$(1.13,1.88)$

0.977

Ref.

$(1.16,1.44)$

0.711

Ref.

$(1.11,1.40)$

0.358

Ref.

$(0.97,1.64) \quad 0.012$

$(0.71,1.12) \quad 0.313$

$(0.71,1.05) \quad 0.979$

Ref.

$(0.99,1.38) \quad 0.384$

$(1.13,1.52) \quad 0.026$

$(1.04,1.44)$

0.936

1.22

$(1.01,1.28)$

0.617

Ref.

$(0.93,1.32) \quad 0.967$

$(1.30,1.96) \quad 0.527$

$(1.26,1.96)$

0.943

Ref.

$(0.92,1.18) \quad 0.948$

$(1.11,1.58) \quad 0.792$

1.32

$(1.83,2.33)$

0.053

$(0.84,1.09)$

0.008

Ref.

$(1.29,1.75) \quad 0.607$

$\begin{array}{ll}(0.99,1.33) & 0.410\end{array}$

$(0.90,1.17) \quad 0.930$

Ref. 
Table 2 Bivariate associations between the explanatory factors and mortality for men and women (Continued)

\begin{tabular}{|c|c|c|c|c|c|}
\hline & \multicolumn{2}{|l|}{ Men } & \multicolumn{2}{|c|}{ Women } & \multirow{2}{*}{$\begin{array}{l}\text { Testing for a gender } \\
\text { difference in the } \\
\text { bivariate associations } \\
(p \text { value })^{c}\end{array}$} \\
\hline & $\overline{H R^{a}}$ & $(95 \% C l)^{b}$ & $\overline{H R^{a}}$ & $(95 \% \mathrm{Cl})^{\mathrm{b}}$ & \\
\hline \multicolumn{6}{|l|}{ Sports activity } \\
\hline Inactive & 1.26 & $(1.09,1.46)$ & 1.41 & $(1.18,1.69)$ & 0.317 \\
\hline Little & 1.12 & $(0.89,1.43)$ & 1.15 & $(0.90,1.47)$ & 0.856 \\
\hline Moderate & 0.96 & $(0.78,1.18)$ & 1.09 & $(0.88,1.35)$ & 0.377 \\
\hline Active & 1 & Ref. & 1 & Ref. & \\
\hline \multicolumn{6}{|l|}{ Family-related factors } \\
\hline \multicolumn{6}{|l|}{ Marital status } \\
\hline Currently married & 1 & Ref. & 1 & Ref. & \\
\hline Previously married & 1.55 & $(1.33,1.79)$ & 1.18 & $(1.05,1.33)$ & 0.008 \\
\hline Never married & 1.55 & $(1.27,1.90)$ & 1.31 & $(1.09,1.58)$ & 0.300 \\
\hline \multicolumn{6}{|l|}{ Living arrangement } \\
\hline Living with partner & 1 & Ref. & 1 & Ref. & \\
\hline Living alone & 1.55 & $(1.35,1.77)$ & 1.21 & $(1.08,1.35)$ & 0.008 \\
\hline \multicolumn{6}{|l|}{ Number of children } \\
\hline 0 & 1.10 & $(0.94,1.28)$ & 1.23 & $(1.04,1.44)$ & 0.288 \\
\hline 1 & 1.01 & $(0.85,1.19)$ & 1.20 & $(1.01,1.43)$ & 0.128 \\
\hline 2 & 1 & Ref. & 1 & Ref. & \\
\hline 3 or more & 0.97 & $(0.86,1.09)$ & 0.92 & $(0.81,1.04)$ & 0.663 \\
\hline
\end{tabular}

Notes. ${ }^{a} \mathrm{HR}$ Hazard ratios. ${ }^{\mathrm{b}} \mathrm{Cl}$ Confidence interval. Mortality hazard ratios of the explanatory variable when controlling for education only. As the Cox regression models included age as timescale, it was unnecessary to also include age as a covariate in the models. 'A possible differential association of these explanatory factors with mortality for men and women was determined by adding an interaction term between the explanatory factor and gender and testing its statistical significance ( $p$ value)

for the separate employment-related factors. Type of employment (and specifically unemployment) explained more of the educational inequalities for men (29\%) than for women $(-7 \%)$, whereas occupation of the breadwinner seemed to explain more for women (41\%) than for men (7\%). Behavioural factors explained a similar proportion of the educational inequalities for men (between 11 and 36\%) and women (between 13 and 37\%). Family factors did not explain educational inequalities for either men or women; they even seemed to slightly strengthen the inequalities for both. When all risk factors were considered, a substantial part of the educational inequalities in mortality was explained for both men (between 33 and 62\%) and women (between 28 and 71\%). The increased HR of the lowest educated men compared to the highest educated men remained borderline statistically significant $(\mathrm{HR}=1.22$, 95\% CI:1.00, 1.49). Results for low and mid educated men and women are presented in Additional file 1: Tables S2 and S3.

\section{Explaining educational inequalities in cause-specific mortality}

All categories of explanatory variables seemed to explain more of the educational inequalities observed in cardiovascular mortality for men (88\%, Table 4) than for women (12\%). For women, educational inequalities in mortality from cardiovascular disease $(\mathrm{HR}=2.08,95 \%$ CI: $1.26,3.44)$ were stronger than those in all-cause mortality $(\mathrm{HR}=1.59,95 \% \mathrm{CI}: 1.25,2.02)$, and they persisted even after controlling for all explanatory factors $(\mathrm{HR}=$ 1.95, 95\% CI: 1.11, 3.41). For men, the risk factors explained less of the educational inequalities in cancer mortality (28\%) than of the educational inequalities in all-cause mortality (62\%). All explanatory variables, with the exception of family-related factors, appeared to explain more of the educational inequalities in cancer mortality for women (112\%) than for men (28\%). With regards to mortality from other diseases, material and family-related factors seemed to explain a larger part of the educational inequalities for men $(94 \%$ and $10 \%$ respectively) than for women $(58 \%$ and $-12 \%$ respectively), whereas employment-related and behavioural factors seemed to explain more for women $30 \%$ and $63 \%$ respectively) than for men $(13 \%$ and $58 \%$ respectively). Our explanatory variables explained some of the elevated mortality risk from external causes for lowest educated women with respect to higher educated women (50\%), but they did not contribute to an explanation for men. 


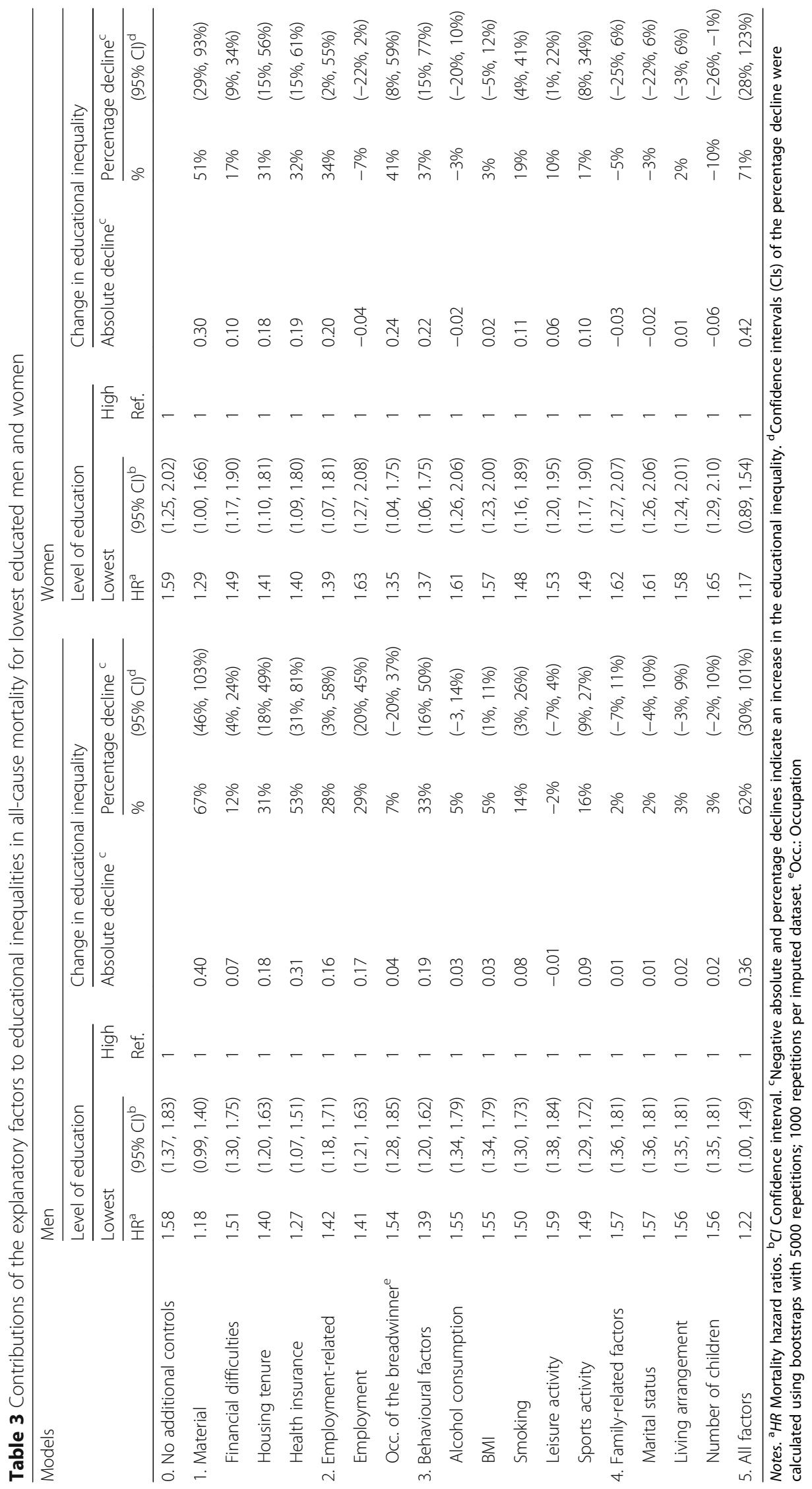


Table 4 Contributions of the explanatory factors to educational inequalities in cause-specific mortality for lowest educated men and women

\begin{tabular}{|c|c|c|c|c|c|c|c|c|c|c|}
\hline \multirow[t]{4}{*}{ Models } & \multicolumn{5}{|l|}{ Men } & \multicolumn{5}{|c|}{ Women } \\
\hline & \multicolumn{3}{|c|}{ Level of education } & \multicolumn{2}{|c|}{ Change in educational inequality } & \multicolumn{3}{|c|}{ Level of education } & \multicolumn{2}{|c|}{ Change in educational inequality } \\
\hline & \multicolumn{2}{|c|}{ Lowest } & \multirow{2}{*}{$\begin{array}{l}\text { High } \\
\text { Ref. }\end{array}$} & \multirow{2}{*}{$\begin{array}{l}\text { Absolute } \\
\text { decline }^{c}\end{array}$} & \multirow{2}{*}{$\begin{array}{l}\text { Percentage } \\
\text { decline }^{c}\end{array}$} & \multicolumn{2}{|c|}{ Lowest } & \multirow{2}{*}{$\begin{array}{l}\text { High } \\
\text { Ref. }\end{array}$} & \multirow{2}{*}{$\begin{array}{l}\text { Absolute } \\
\text { decline }^{c}\end{array}$} & \multirow{2}{*}{$\begin{array}{l}\text { Percentage } \\
\text { decline }^{c}\end{array}$} \\
\hline & $\overline{H R^{a}}$ & $(95 \% \mathrm{Cl})^{\mathrm{b}}$ & & & & $\mathrm{HR}^{\mathrm{a}}$ & $(95 \% \mathrm{Cl})^{\mathrm{b}}$ & & & \\
\hline \multicolumn{11}{|c|}{ Mortality from cardiovascular disease $^{d}$} \\
\hline 0. No additional controls & 1.58 & $(1.23,2.04)$ & 1 & & & 2.08 & $(1.26,3.44)$ & 1 & & \\
\hline 1. Material & 1.25 & $(0.91,1.71)$ & 1 & 0.33 & $57 \%$ & 2.13 & $(1.27,3.57)$ & 1 & -0.05 & $-5 \%$ \\
\hline 2. Employment-related & 1.17 & $(0.84,1.62)$ & 1 & 0.41 & $71 \%$ & 1.90 & $(1.11,3.24)$ & 1 & 0.18 & $17 \%$ \\
\hline 3. Behavioural & 1.39 & $(1.06,1.81)$ & 1 & 0.19 & $33 \%$ & 1.87 & $(1.11,3.16)$ & 1 & 0.21 & $19 \%$ \\
\hline 4. Family-related & 1.57 & $(1.21,2.03)$ & 1 & 0.01 & $2 \%$ & 2.02 & $(1.22,3.32)$ & 1 & 0.06 & $6 \%$ \\
\hline 5. All factors & 1.07 & $(0.75,1.52)$ & 1 & 0.51 & $88 \%$ & 1.95 & $(1.11,3.41)$ & 1 & 0.13 & $12 \%$ \\
\hline \multicolumn{11}{|l|}{ Cancer mortality $^{\mathrm{e}}$} \\
\hline 0. No additional controls & 1.50 & $(1.20,1.89)$ & 1 & & & 1.33 & $(0.91,1.95)$ & 1 & & \\
\hline 1. Material & 1.26 & $(0.96,1.66)$ & 1 & 0.24 & $48 \%$ & 1.04 & $(0.70,1.55)$ & 1 & 0.29 & $88 \%$ \\
\hline 2. Employment-related & 1.52 & $(1.14,2.04)$ & 1 & -0.02 & $-4 \%$ & 1.14 & $(0.75,1.73)$ & 1 & 0.19 & $58 \%$ \\
\hline 3. Behavioural & 1.33 & $(1.05,1.69)$ & 1 & 0.17 & $34 \%$ & 1.21 & $(0.82,1.79)$ & 1 & 0.12 & $36 \%$ \\
\hline 4. Family-related & 1.50 & $(1.19,1.88)$ & 1 & 0.00 & $0 \%$ & 1.38 & $(0.94,2.04)$ & 1 & -0.05 & $-15 \%$ \\
\hline 5. All factors & 1.36 & $(1.00,1.86)$ & 1 & 0.14 & $28 \%$ & 0.96 & $(0.61,1.49)$ & 1 & 0.37 & $112 \%$ \\
\hline \multicolumn{11}{|l|}{ Mortality from other diseases ${ }^{f}$} \\
\hline 0. No additional controls & 1.31 & $(0.99,1.74)$ & 1 & & & 1.43 & $(0.94,2.19)$ & 1 & & \\
\hline 1. Material & 1.02 & $(0.73,1.43)$ & 1 & 0.29 & $94 \%$ & 1.18 & $(0.77,1.82)$ & 1 & 0.25 & $58 \%$ \\
\hline 2. Employment-related & 1.27 & $(0.89,1.81)$ & 1 & 0.04 & $13 \%$ & 1.30 & $(0.83,2.05)$ & 1 & 0.13 & $30 \%$ \\
\hline 3. Behavioural & 1.13 & $(0.83,1.53)$ & 1 & 0.18 & $58 \%$ & 1.16 & $(0.75,1.80)$ & 1 & 0.27 & $63 \%$ \\
\hline 4. Family-related & 1.28 & $(0.96,1.71)$ & 1 & 0.03 & $10 \%$ & 1.48 & $(0.96,2.27)$ & 1 & -0.05 & $-12 \%$ \\
\hline 5. All factors & 1.03 & $(0.70,1.51)$ & 1 & 0.28 & $90 \%$ & 1.06 & $(0.66,1.72)$ & 1 & 0.37 & $86 \%$ \\
\hline \multicolumn{11}{|l|}{ Mortality from external causes ${ }^{9}$} \\
\hline 0. No additional controls & 0.95 & $(0.39,2.32)$ & 1 & & & 2.05 & $(0.48,8.77)$ & 1 & & \\
\hline 1. Material & 1.17 & $(0.38,3.63)$ & 1 & -0.22 & $-440 \%$ & 1.66 & $(0.35,8.00)$ & 1 & 0.39 & $37 \%$ \\
\hline 2. Employment-related & 1.21 & $(0.32,4.54)$ & 1 & -0.26 & $-520 \%$ & 1.27 & $(0.30,5.45)$ & 1 & 0.78 & $74 \%$ \\
\hline 3. Behavioural & 1.04 & $(0.41,2.61)$ & 1 & -0.09 & $-180 \%$ & 2.27 & $(0.51,10.04)$ & 1 & -0.22 & $-21 \%$ \\
\hline 4. Family-related & 0.98 & $(0.39,2.44)$ & 1 & -0.03 & $-60 \%$ & 2.20 & $(0.50,9.65)$ & 1 & -0.15 & $-14 \%$ \\
\hline 5. All factors & 1.42 & $(0.37,5.42)$ & 1 & -0.47 & $-940 \%$ & 1.52 & $(0.28,8.22)$ & 1 & 0.53 & $50 \%$ \\
\hline
\end{tabular}

Notes. ${ }^{a} \mathrm{HR}$ Mortality hazard ratios. ${ }^{\mathrm{b}} \mathrm{Cl}$ Confidence interval. ${ }^{\mathrm{c}}$ Negative absolute and percentage declines indicate an increase in the educational inequality. ${ }^{\mathrm{d}}$ Mortality from cardiovascular disease includes deaths with International Classification of Diseases (ICD) [36] codes between I00 and I99. ${ }^{\text {e}}$ Cancer mortality includes deaths with ICD codes between C00 and D48. 'Mortality from other diseases includes deaths with all other ICD codes than those included in cardiovascular disease, cancer or external causes. ${ }^{9}$ Mortality from external causes includes deaths with ICD codes between V01 and Y 89

\section{Discussion}

Educational gradients in mortality were found for both men and women. Although a substantial and reasonably similar part of the educational inequalities in mortality was explained by all material, employment-related, behavioural and family-related factors together for both men (62\%) and women (71\%), the specific contributions of some factors differed between men and women. Specifically, type of employment explained more of the educational inequalities in all-cause mortality for men than for women, whereas the occupational class of the breadwinner explained more for women than for men. Our results also suggested that material and employment-related factors contribute more to inequalities in mortality from cardiovascular diseases for men than for women, but they explained more of the inequalities in cancer mortality for women than for men.

\section{Methodological considerations}

Besides a mortality follow-up of more than 20 years, a major strength of this study is the inclusion of a broad selection of material, employment-related, behavioural and 
family-related factors. However, these factors were self-reported and may contain measurement error. If biases in self-reports differed by education or gender, for which evidence exists, this may have affected our results. For example, in the French GAZEL study, men underestimated their weight and overestimated their height less than women, and high educated men and women overestimated their height less than their low educated counterparts [41]. Differences in self-reporting biases by gender or education have also been found for other (behavioural) factors, including physical activity [42] and smoking [43]. Yet, the exact direction of self-report misclassification by gender and socioeconomic status is less clear.

In this study, we examined the contribution of single measurements of material, employment, behavioural and family factors to educational inequalities in mortality. It may be argued that using multiple measurements of the explanatory variables would be better as it allows to account for possible changes over time in inequalities in these variables. Recent studies have shown that the contribution of behavioural factors to socioeconomic inequalities in mortality was (slightly) larger when multiple measurements over time of these factors were included [44-46]. Using the same GLOBE data, Oude Groeniger and colleagues also found a larger contribution of behavioural factors to educational inequalities in mortality when multiple measurements were used, but a smaller contribution of material factors [47]. Yet, another study found a slightly higher attenuation of educational inequalities in mortality for men when behavioural, psychosocial, biomedical risk factors and employment were measured twice (63\%, compared to $53 \%$ when only the baseline measurement was used), but no change in the attenuation for women [48]. We believe our overall conclusions to be valid, as by using only a single measurement we may have slightly underestimated the contribution of behavioural factors and slightly overestimated the contribution of material factors to socioeconomic inequalities in mortality.

Longitudinal data on the explanatory variables was available but only for two subsamples of the GLOBE study $(N=5667)$. After exclusion of the chronically ill and respondents with missing information on any of the other variables, the final sample would be even smaller. As our main focus was on estimating gender differences in the explanations of educational inequalities in mortality, we decided to use the baseline sample. We believe that misclassification bias due to changes in educational status during the 23 years of follow-up is relatively small as our sample exists of individuals aged 25 years and over, who are likely to have finished their education. Second, using the longitudinal data from the GLOBE study, Oude Groeniger and colleagues found that although the contribution of behavioural and material factors to explaining educational inequalities in mortality changed when these factors were measured multiple times, they did not observe clear gender differences in these changes [47]. Based on these findings, we therefore do not believe that differential changes in the explanatory factors by gender would contribute to explaining the observed differences.

Despite the fact that we used a broad set of material, employment-related, behavioural and family-related factors in our study, it may be argued that inclusion of more specific explanatory factors should be considered. To the extent that the prevalence of such specific measures and their association with mortality differs between men and women, including them could have led to more specific estimations of the contribution of the explanatory factors. For example, dietary intake, e.g. fruit and vegetable consumption, is educationally patterned [49], and may play a more important role in explaining educational inequalities in mortality than a summary measure such as BMI. Unfortunately our data did not allow us to include these more specific measures, but we strongly encourage future studies to consider these factors and examine their contribution to explaining educational inequalities in mortality.

Finally, although the study population of the GLOBE study is reasonably representative for the Dutch ethnic population, residents of non-Western ethnicities were almost absent in the baseline measurement [31]. Generalizing our findings to other populations or countries should therefore be done with caution.

\section{Interpretation}

Overall, we found a similar contribution of material and behavioural factors to socioeconomic inequalities in all-cause mortality for both men and women. Of all explanatory variables, material factors contributed most to the explanation of educational inequalities in mortality. This finding is in line with previous research $[7,8,10]$. Behavioural factors also provided a substantial contribution to educational inequalities in all-cause mortality in our study; our estimates fit the broad range of contributions reported by previous studies, including a $56 \%$ reduction of the educational gradient in mortality in the British Whitehall study and a $17 \%$ reduction in the French GAZEL study [12].

However, type of employment was more important in explaining educational inequalities in all-cause mortality for men than for women. Unemployment was more strongly associated with mortality and more strongly educational patterned among men than among women. In contrast, the occupational class of the breadwinner was more important in explaining educational inequalities in mortality for women than for men. Although a weaker educational gradient in blue-collar occupation of 
the breadwinner was found among women than among men, its stronger association with mortality for women resulted in a larger contribution of this factor to the explanation of educational inequalities in mortality for women than for men. As a large proportion of the women in our sample were outside the labour force, i.e. $57 \%$ of all women, the occupational class of the breadwinner may thus possibly be a better representative of their social class than their own employment status. However, for men it seemed that having a job outweighed the prestige associated with that job. This is likely to explain the gender differences in the contribution of our employment-related factors to explaining educational inequalities in mortality. However, we did not find evidence of gender differences in the explanation of educational inequalities in mortality for the other explanatory variables. Thus even though there were gender differences in the educational gradient as well as the association with mortality for some of our other variables (e.g. being previously married and living alone), our results showed that these differences were not large enough to lead to gender differences in explanations or were compensating each other.

Besides material, employment-related and behavioural factors, we also examined whether family-related factors play a role in explaining educational inequalities in mortality, as we know that they are associated with mortality. Our results suggest that marital status, living arrangement and number of children did not contribute to the explanation of socioeconomic inequalities in mortality for either men or women. For example, even though being previously married was more strongly associated with mortality for men than for women, marital status was less socially patterned among men than women, and thus no significant differences in the contribution of marital status to socioeconomic inequalities in mortality by gender were found. Our results may well have depended on the relatively broad measures of family-related factors, such as legal marital status and the number of children in the household, that were included. Therefore, we recommend future studies to take into account more specific family-related factors or even full family life histories in a longitudinal analysis, to advance our knowledge on how family-related factors may contribute to educational inequalities in mortality.

In the cause-specific analysis, we found that our explanatory variables explained a substantial part of educational inequalities in mortality for cardiovascular disease (CVD) for men, but not for women. Our results are partly in line with previous results [50]; a substantial contribution of material factors in the explanation of educational inequalities in CVD mortality for men, and the largest contribution of behavioural factors in the explanation of educational inequalities in CVD mortality for women. Surprisingly however, material factors did not contribute to the explanation of educational inequalities in CVD mortality for women, but it explained a substantial part of their educational inequalities in all-cause mortality and mortality from the other causes (cancer, other diseases, and external causes). This warrants further investigation.

\section{Conclusions}

Our findings highlight the importance of a gender perspective in research on educational inequalities in mortality and the factors contributing to the explanation of these inequalities, as the contributions of these factors differed for men and women. Policies targeting the reduction of educational inequalities in mortality should focus on improving material circumstances and discouraging unhealthy behaviours, and would also benefit from a gendered approach as interventions addressing specific factors may have differential effects on educational inequalities for men and women.

In conclusion, unemployment seemed more important in explaining educational inequalities in mortality for men than for women, whereas social class of the breadwinner was more important for the explanation for women than for men. A full understanding of educational inequalities in mortality thus benefits from a gender perspective, particularly when considering employment-related factors.

\section{Additional file}

Additional file 1: Table S1. Age-standardised distribution of educational level for men and women, at baseline 1991. Table S2. Contributions of the explanatory factors to educational inequalities in all-cause mortality for low educated men and women. Table S3. Contributions of the explanatory factors to educational inequalities in all-cause mortality for mid educated men and women. (DOCX 63 kb)

\section{Abbreviations}

BMI: Body Mass Index; Cl: Confidence Interval; CVD: Cardiovascular Disease; HR: Hazard Ratio; ICD: International Classification of Diseases; ISCED: International Standard Classification of Education

\section{Funding}

This work was supported by a grant from the Netherlands Organization for Health Research and Development (grant number 200500005). The study sponsor had no role in the study design, the collection, analysis and interpretation of the data, the writing of the manuscript, and the decision to submit the manuscript for publication.

\section{Availability of data and materials}

The data that support the findings of this study are available from Statistics Netherlands and the GLOBE study but restrictions apply to the availability of these data, which were used under license for the current study, and so are not publicly available.

\section{Authors' contributions}

$\mathrm{KH}, \mathrm{FJ}$, and JPM conceptualized the research project. KH and JOG analyzed the data. All authors interpreted the results. $\mathrm{KH}$ and FJL wrote the article. JOG and JPM revised and commented on all versions of the article. All authors approved the final version of the article. 


\section{Ethics approval and consent to participate}

Ethics approval regarding the study protocol was received from the Medisch Ethische Toetsings Commissie (Medical Ethical Review Committee) of the Erasmus MC Rotterdam (letter reference: 2262ee98JM). The use of personal data in the GLOBE study is in compliance with the Dutch Personal Data Protection Act and the Municipal Database Act, and has been registered with the Dutch Data Protection Authority (number 1248943).

\section{Consent for publication}

Not applicable.

\section{Competing interests}

The authors declare that they have no competing interests.

\section{Publisher's Note}

Springer Nature remains neutral with regard to jurisdictional claims in published maps and institutional affiliations.

\section{Author details}

'Department of Public Health, Erasmus MC, P.O. Box 2040, 3000, CA, Rotterdam, The Netherlands. ${ }^{2}$ Max Planck Institute for Demographic Research, Rostock, Germany.

\section{Received: 6 February 2018 Accepted: 7 August 2018}

\section{Published online: 10 September 2018}

\section{References}

1. Kunst AE, Mackenbach JP. The size of mortality differences associated with educational level in nine industrialized countries. Am J Public Health. 1994; 84:932-7.

2. Mackenbach JP, Kunst AE, Cavelaars AE, Groenhof F, Geurts JJ. Socioeconomic inequalities in morbidity and mortality in western Europe. Lancet. 1997;349:1655-9.

3. Doornbos G, Kromhout D. Educational level and mortality in a 32-year follow-up study of 18-year-old men in the Netherlands. Int J Epidemiol. 1990;19:374-9

4. Kulhánová I, Hoffmann R, Eikemo TA, Menvielle G, Mackenbach JP. Educational inequalities in mortality by cause of death: First national data for the Netherlands. Int J Public Health. 2014;59:687-96.

5. Mackenbach JP, Stirbu I, Roskam A-JR, Schaap MM, Menvielle G, Leinsalu M, et al. Socioeconomic inequalities in health in 22 European countries. N Engl J Med. 2008;358:2468-81.

6. Huisman M, Kunst AE, Bopp M, Borgan J-K, Borrell C, Costa G, et al. Educational inequalities in cause-specific mortality in middle-aged and older men and women in eight western European populations. Lancet. 2005;365: 493-500.

7. Skalická V, van Lenthe F, Bambra C, Krokstad S, Mackenbach J. Material, psychosocial, behavioural and biomedical factors in the explanation of relative socio-economic inequalities in mortality: Evidence from the HUNT study. Int J Epidemiol. 2009;38:1272-84.

8. van Oort FVA, van Lenthe FJ, Mackenbach JP. Material, psychosocial, and behavioural factors in the explanation of educational inequalities in mortality in the Netherlands. J Epidemiol Community Health. 2005;59: $214-20$

9. Khang Y-H, Lynch JW, Yang S, Harper S, Yun S-C, Jung-Choi K, et al. The contribution of material, psychosocial, and behavioral factors in explaining educational and occupational mortality inequalities in a nationally representative sample of South Koreans: Relative and absolute perspectives. Soc Sci Med. 2009;68:858-66.

10. Schrijvers $C T$, Stronks $K$, van de Mheen HD, Mackenbach JP. Explaining educational differences in mortality: The role of behavioral and material factors. Am J Public Health. 1999;89:535-40.

11. Lantz PM, House JS, Lepkowski JM, Williams DR, Mero RP, Chen J. Socioeconomic factors, health behaviors, and mortality: Results from a nationally representative prospective study of US adults. JAMA. 1998;279: 1703.

12. Stringhini S, Dugravot A, Shipley M, Goldberg M, Zins M, Kivimäki M, et al. Health behaviours, socioeconomic status, and mortality: Further analyses of the British Whitehall II and the French GAZEL prospective cohorts. PLoS Med. 2011;8:e1000419.
13. Mackenbach JP, Kunst AE, Groenhof F, Borgan JK, Costa G, Faggiano F, et al. Socioeconomic inequalities in mortality among women and among men: An international study. Am J Public Health. 1999;89:1800-6.

14. Mustard C, Etches J. Gender differences in socioeconomic inequality in mortality. J Epidemiol Community Health. 2003;57:974-80.

15. Roskam AJR, Kunst AE, Van Oyen H, Demarest S, Klumbiene J, Regidor E, et al. Comparative appraisal of educational inequalities in overweight and obesity among adults in 19 European countries. Int J Epidemiol. 2010;39: 392-404.

16. Huisman M, Kunst AE, Mackenbach JP. Inequalities in the prevalence of smoking in the European Union: Comparing education and income. Prev Med. 2005;40:756-64.

17. Roelfs DJ, Shor E, Davidson KW, Schwartz JE. Losing life and livelihood: A systematic review and meta-analysis of unemployment and all-cause mortality. Soc Sci Med. 2011;72:840-54.

18. Isen A, Stevenson B. Women's education and family behavior: Trends in marriage, divorce and fertility [Internet]. Cambridge: National Bureau of Economic Research; 2010. Report No.: w15725. Available from: http://www. nber.org/papers/w15725.pdf. Accessed 20 Nov 2016.

19. Centraal Bureau voor de Statistiek. Fertility of men and women by educational level (Vruchtbaarheid van mannen en vrouwen naar opleidingsniveau) [Internet]. 2012 [cited 2016 Nov 20]. Available from: https://www.cbs.nl/nl-nl/achtergrond/2012/37/vruchtbaarheid-van-mannenen-vrouwen-naar-opleidingsniveau

20. Hu YR, Goldman N. Mortality differentials by marital status: An international comparison. Demography. 1990;27:233-50.

21. Koskinen S, Joutsenniemi K, Martelin T, Martikainen P. Mortality differences according to living arrangements. Int J Epidemiol. 2007;36:1255-64.

22. Grundy $E$, Kravdal $\varnothing$. Reproductive history and mortality in late middle age among Norwegian men and women. Am J Epidemiol. 2008;167:271-9.

23. Gove WR. Sex, marital status, and mortality. Am J Sociol. 1973;79:45-67.

24. Weatherall $\mathrm{R}$, Joshi $\mathrm{H}$, Macran $\mathrm{S}$. Double burden or double blessing? Employment, motherhood and mortality in the longitudinal study of England and Wales. Soc Sci Med. 1994;38:285-97.

25. Hibbard JH, Pope CR. Effect of domestic and occupational roles on morbidity and mortality. Soc Sci Med. 1991;32:805-11.

26. Laaksonen M. Influence of material and behavioural factors on occupational class differences in health. J Epidemiol Community Health. 2005:59:163-9.

27. Aldabe $B$, Anderson $R$, Lyly-Yrjänäinen $M$, Parent-Thirion $A$, Vermeylen $G$, Kelleher CC, et al. Contribution of material, occupational, and psychosocial factors in the explanation of social inequalities in health in 28 countries in Europe. J Epidemiol Community Health. 2011;65:1123-31.

28. Richter M, Moor I, van Lenthe FJ. Explaining socioeconomic differences in adolescent self-rated health: The contribution of material, psychosocial and behavioural factors. J Epidemiol Community Health. 2012;66:691-7.

29. Hiyoshi A, Fukuda Y, Shipley MJ, Brunner EJ. Health inequalities in Japan: The role of material, psychosocial, social relational and behavioural factors, Soc Sci Med. 2014;104:201-9.

30. Mackenbach JP, van de Mheen H, Stronks K. A prospective cohort study investigating the explanation of socio-economic inequalities in health in the Netherlands. Soc Sci Med. 1994:38:299-308.

31. van Lenthe FJ, Kamphuis CB, Beenackers MA, Jansen T, Looman CW, Nusselder WJ, et al. Cohort profile: Understanding socioeconomic inequalities in health and health behaviours: The GLOBE study. Int $J$ Epidemiol. 2014;43:721-30.

32. van Lenthe FJ, Schrijvers CTM, Droomers M, Joung IMA, Louwman MJ, Mackenbach JP. Investigating explanations of socio-economic inequalities in health. Eur J Pub Health. 2004;14:63-70.

33. Sociaal-Economische Raad. Werk: van belang voor iedereen. Een advies over werken met een chronische ziekte. [Internet]. 2016. Available from: https:/ www.ser.nl/ /media/db_adviezen/2010_2019/2016/werken-chronischeziekte.ashx. Accessed 13 Sept 2017.

34. UNESCO. International standard classification of education: ISCED 1997 [Internet]. 1997 [cited 2014 Sep 29]. Available from: http://www.unesco.org/ education/information/nfsunesco/doc/isced_1997.htm

35. Erikson R, Goldthorpe JH. The constant flux: Study of class mobility in industrial societies. Oxford: Clarendon Press; 1992.

36. World Health Organization. International Statistical Classification of Diseases and Related Health Problems. 10th Revision [Internet]. 2011. Available from: http://apps.who.int/classifications/icd10/browse/Content/statichtml/ ICD10Volume2_en_2010.pdf. Accessed 21 Nov 2017. 
37. Zhang P. Multiple imputation: Theory and method. Int Stat Rev. 2007;71: $581-92$.

38. Sterne JAC, White IR, Carlin JB, Spratt M, Royston P, Kenward MG, et al. Multiple imputation for missing data in epidemiological and clinical research: Potential and pitfalls. BMJ. 2009;338:b2393.

39. Baron RM, Kenny DA. The moderator-mediator variable distinction in social psychological research: Conceptual, strategic, and statistical considerations. J Pers Soc Psychol. 1986;51:1173-82.

40. Andersen PK, Geskus RB, de Witte T, Putter H. Competing risks in epidemiology: Possibilities and pitfalls. Int J Epidemiol. 2012;41:861-70.

41. Niedhammer I, Bugel I, Bonenfant S, Goldberg M, Leclerc A. Validity of selfreported weight and height in the French GAZEL cohort. Int J Obes. 2000; 24:1111-8.

42. Winckers ANE, Mackenbach JD, Compernolle S, Nicolaou M, van der Ploeg HP, De Bourdeaudhuij I, et al. Educational differences in the validity of selfreported physical activity. BMC Public Health. 2015;15:1299.

43. Caraballo RS, Giovino GA, Pechacek TF, Mowery PD. Factors associated with discrepancies between self-reports on cigarette smoking and measured serum cotinine levels among persons aged 17 years or older third National Health and nutrition examination survey, 1988-1994. Am J Epidemiol. 2001; 153:807-14.

44. Stringhini S, Sabia S, Shipley M, et al. Association of socioeconomic position with health behaviors and mortality. JAMA. 2010;303:1159-66.

45. Mehta NK, House JS, Elliot MR. Dynamics of health behaviours and socioeconomic differences in mortality in the USA. J Epidemiol Community Health. 2015;69:416-22.

46. Ariansen I, Graff-Iversen S, Stigum H, Strand BH, Wills AK, Næss $\varnothing$. Do repeated risk factor measurements influence the impact of education on cardiovascular mortality? Heart. 2015;101:1889.

47. Oude Groeniger J, Kamphuis CB, Mackenbach JP, van Lenthe FJ. Repeatedly measured material and behavioral factors changed the explanation of socioeconomic inequalities in all-cause mortality. J Clin Epidemiol. 2017;91: 137-45.

48. Skalická V, Ringdal K, Witvliet MI. Socioeconomic inequalities in mortality and repeated measurement of explanatory risk factors in a 25 years followup. PLoS One. 2015;e0124690:10

49. Irala-Estevez JD, Groth M, Johansson L, Oltersdorf U, Prättälä R, MartínezGonzález MA. A systematic review of socio-economic differences in food habits in Europe: consumption of fruit and vegetables. Eur J Clin Nutr. 2000; 54:706-14.

50. Kamphuis CB, Turrell G, Giskes K, Mackenbach JP, van Lenthe FJ. Socioeconomic inequalities in cardiovascular mortality and the role of childhood socioeconomic conditions and adulthood risk factors: A prospective cohort study with 17-years of follow up. BMC Public Health. 2012;12:1045.

Ready to submit your research? Choose BMC and benefit from:

- fast, convenient online submission

- thorough peer review by experienced researchers in your field

- rapid publication on acceptance

- support for research data, including large and complex data types

- gold Open Access which fosters wider collaboration and increased citations

- maximum visibility for your research: over $100 \mathrm{M}$ website views per year

At $\mathrm{BMC}$, research is always in progress.

Learn more biomedcentral.com/submissions 